\title{
SOME SURFACE CHARACTERISTICS OF ORIENTAL BEECH WOOD IMPREGNATED WITH SOME FIRE-RETARDANTS AND COATED WITH POLYUREA/POLYURETHANE HYBRID AND EPOXY RESINS
}

\author{
Çağlar Altay ${ }^{1, \triangleleft}$ \\ https://orcid.org/0000-0003-1286-8600 \\ Hilmi Toker ${ }^{2}$ \\ https://orcid.org/0000-0002-1900-9887 \\ Ergün Baysal \\ https://orcid.org/0000-0002-6299-2725 \\ Ilknur Babahan \\ https://orcid.org/0000-0001-6081-4899
}

\begin{abstract}
This study was made to determine surface characteristics such as colour, gloss, and surface hardness changes of Oriental beech (Fagus orientalis). The wood specimens were firstly impregnated with some fireretardants (FRs) and primed with epoxy resin (EPR) and then coated with polyurethane/polyurea hybrid resin (PUU). Oriental beech was impregnated with $3 \%$ aqueous solution of boric acid (BA), borax (BX), boric acid and borax mixture (1:1), and ammonium sulphate (AS). While Sikafloor ${ }^{\circledR}-156$ was used for epoxy coating (EPR), Sikalastic ${ }^{\circledR}-851 \mathrm{R}$ was used for polyurethane/polyurea hybrid coating (PUU). According to our results, all treatment groups gave negative lightness stability values after accelerated weathering. The colour stability of epoxy resin coated Oriental beech was higher than that of polyurethane/polyurea hybrid resin coated Oriental beech. Except for boric acid impregnated and polyurethane/polyurea hybrid resin coated Oriental beech, all fire-retardants treatment before polyurethane/polyurea hybrid resin and epoxy resin coatings decreased the gloss losses of Oriental beech after accelerated weathering. Fire-retardants impregnation before epoxy resin and polyurethane/polyurea hybrid resin coatings improved the surface hardness values of Oriental beech after accelerated weathering.
\end{abstract}

Keywords: Epoxy coating, fire retardants, oriental beech, polyurea coating, polyurethane coating, surface characteristics.

\footnotetext{
${ }^{1}$ Aydın Adnan Menderes University, Aydın Vocational School, Department of Interior Design, Aydın, Turkey.

${ }^{2}$ Muğla Sttkı Koçman University, Faculty of Technology, Department of Wood Science and Technology, Mugla, Turkey.

${ }^{3}$ Aydın Adnan Menderes University, Faculty of Arts and Sciences, Department of Chemistry, Aydın, Turkey.

•Corresponding author: caglar.altay@adu.edu.tr
}

Received: 08.04.2021 Accepted: 18.10.2021 


\section{INTRODUCTION}

Preserving the visual structure of wood posed a very important problem. Wood is degraded by biotic/ abiotic effects, especially in outdoor conditions. Climatic changes exhibit a weathered appearance in the wood (Peker 1997). In weathering exposure, the effect of sun rays on the wood changes the wood color very rapidly, and it causes losses in hardness, brightness, and mechanical properties. This is reported to be caused by wood extractives and chemical degradation of lignin (Budakçı 2006, Anderson et al. 1991, Sivrikaya et al. 2011). The expectation of better protection of wood, which plays an important role in the world economy, especially in the field of construction and furniture, during storage, transportation, manufacturing and service continues to be up to date (González-Laredo et al. 2015). For this, many different methods are applied within the "wood preservation" discipline (Söğütlü and Döngel 2009). One of these methods is impregnation. Impregnation means trying to penetrate the protective materials of different character, which try to minimize the effects of the hazards in the area of use, to extend the service life of the wood, using pressurized/non-pressure methods. In this sense, simple techniques such as dipping and spraying can be used (Aslan and Özkaya 2009), as well as more advanced techniques that apply pressure/vacuum (Ö̈zgenç et al. 2013). The most effective method of preventing the photodegradation of wood involves treating inorganic salts with dilute aqueous solutions, particularly hexavalent chromium compounds (Evans et al. 1992). The most common method for protecting wood against weathering factors and photodegradation is the use of coatings such as paints with UV absorbers and/or antioxidants, varnishes, strains, organic finishes, or water repellents (Evans et al. 1992). It has become up-to-date in coating with top surface materials (paint, polish and varnish) in addition to impregnation to further increase the service life of wood and protect it against weathering conditions. For this reason, several studies have reported that impregnation and varnishing both contribute to the long-term protection of wood surface properties against weathering. Gündüz et al. (2019), Gündüz et al. (2020) studied colour, gloss, and surface hardness changes of Scots pine impregnated with copper-based chemicals and then varnished with polyurethane, cellulosic, and water-based varnish after accelerated weathering. They found that copperbased chemicals impregnation before three varnishes coating improved surface properties of Scots pine wood specimens after accelerated weathering. Türkoğlu et al. (2015) investigated the effects of natural weathering on colour stability of Scots pine (Pinus sylvestris L.) and Oriental beech (Fagus orientalis L.) treated with some chemicals such as tanalith-E TN-E, adolit-KD5, and chromated copper arsenate and then coated with synthetic and polyurethane varnishes. They found that the color stability of treated and varnished Scots pine showed better colour stability than un-treated and solely varnish coated Scots pine specimens after weathering.

In the literature, there are studies on some surface characteristics of wood impregnated with some chemicals and coated with some coating materials after weathering or accelerated weathering. However, there are almost no studies of fire retardants impregnated and polyurea/polyurethane and epoxy resins coated wood after accelerated weathering. For this purpose, this study has been tried for the first time in the literature. In order to obtain new coatings materials that can improve the color, gloss and the surface hardness of the wood, a two-step coating method was applied in this study. An impregnation method was applied by using FRs which are boron chemicals and ammonium sulphate before coating process. Firstly, the wood specimens were primed with epoxy resin by using Sikafloor ${ }^{\mathbb{B}}-156$ (EPR), and then coated with Sikalastic ${ }^{\mathbb{B}}-851$ R, a polyurethane/ polyurea hybrid resin. Some surface characteristics of Oriental beech wood such as colour, gloss, and surface hardness were investigated, as well.

\section{MATERIALS AND METHODS}

\section{Preparation of test specimens}

Oriental beech (Fagus orientalis L.) wood was prepared in $6 \mathrm{~mm}$ x $75 \mathrm{~mm} \times 150 \mathrm{~mm}$ (radial, tangential, and longitudional) dimensions for colour, gloss, and surface hardness tests.

\section{Impregnation procedure}

Boric acid $\left(\mathrm{H}_{3} \mathrm{BO}_{3}\right.$; CAS: 10043-35-3), borax $\left(\mathrm{Na}_{2} \mathrm{~B}_{4} \mathrm{O}_{7} .10 \mathrm{H}_{2} \mathrm{O}\right.$; CAS 1303-96-4; di-sodium tetraborate decahydrate) and ammonium sulphate $\left(\left(\mathrm{NH}_{4}\right)_{2} \mathrm{SO}_{4}\right.$; CAS: 7783-20-2) were purchased from Merck and used to prepare the solutions. The impregnation of the Oriental beech was carried out according to ASTM D 1413-07 (2007). The amount of FRs retention was determined from the following equation (Equation 1). 


$$
\text { Retention }=\frac{G C}{100 \times V}\left(\mathrm{~kg} / \mathrm{m}^{3}\right)
$$

Where;

$\mathrm{G}=\mathrm{T}_{2}-\mathrm{T}_{1}$

$\mathrm{T}_{1}=$ First weight of the specimen $(\mathrm{kg})$

$\mathrm{T}_{2}=$ Final weight of the specimen $(\mathrm{kg})$

$\mathrm{V}=$ Volume of the specimen $\left(\mathrm{m}^{3}\right)$

$\mathrm{C}=$ Concentration $(\%)$

\section{Coating procedure}

The coatings are based on epoxy and polyurethanelpolyurea hybrid resins. The impregnated wood was primed with epoxy resin components $\left(\right.$ Sikafloor $\left.^{\mathbb{B}}-156\right)$ and then coated with polyurethane/polyurea hybrid resin (Sikalastic ${ }^{\circledR}-851 \mathrm{R}$ ). Epoxy coated wood is labelled as EPR (Figure 1a, Figure 1b) and polyurethanel polyurea coated wood is labelled as PUU, as well (depicted in Figures 2a). PUU labelled wood determine that the coatings were firstly primed with epoxy resin and then coated with polyurethane/polyurea hybrid resin.

\section{EPR Coatings}

Sikafloor ${ }^{\circledR}-156$ was used as an epoxy resin for EPR coatings. Sikafloor-156 is purchased from Sika company in Turkey. Sikafloor ${ }^{\mathbb{B}}-156$ is well-known as a epoxy primer with two ingredents, which is consists of an epoxy part (A) and a hardener part (B), low-viscosity and solvent-free (Abed et al. 2020). In line with the manufacturer's recommendations, 3 components A and 1 component $\mathrm{B}$ components were combined and applied to 2 layers of wood material. It was applied to the impregnated wood by the professional users of the epoxy resin manufacturer company in Aydın Adnan Menderes University Furniture and Decoration Workshop (depicted in Figure 1a).

The possible cure reaction between an epoxy part and a hardener part is given in Figure 1b. The hardeners are known the chemicals which are converted epoxy resin to thermosets, have usually bear active hydrogen attacted to an electronegative atom such as, $\mathrm{N}, \mathrm{O}$ or $\mathrm{S}$. The curing reaction is a ring opening reaction between the oxirane ring and a nucleophile (Figure $1 \mathrm{~b}$ ). The ring opening reaction occurs via nucleophilic attack by the hardener to the oxirane ring, then a second reaction follows until the remaining active hydrogens attached to the hardeners are fully reacted (Babahan et al. 2020).

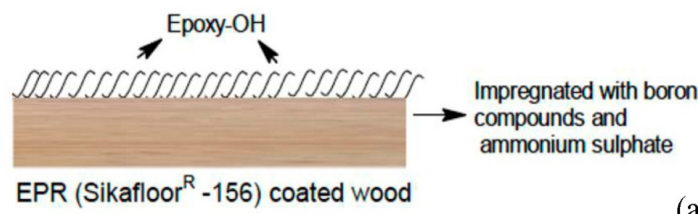

(a)

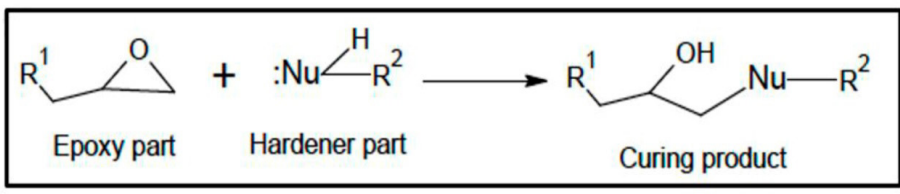

(b)

Figure 1: (a) EPR coated wood, (b) Possible curing reaction between epoxy part and hardener part for EPR coatings. 


\section{PUU Coatings}

Sikalastic ${ }^{\circledR}-851 \mathrm{R}$ was used for PUU coatings. Sikalastic ${ }^{\circledR}-851 \mathrm{R}$ is also obtained from Sika company in Turkey. PUU coated by using Sikalastic ${ }^{\circledR}-851 \mathrm{R}$ resin were made after test specimens were primed with epoxy resin (Sikafloor ${ }^{\circledR}$-156). Sikalastic ${ }^{\circledR}-851 \mathrm{R}$ is known as a two component, elastic, crack-bridging, rapid-curing modified polyurethane/polyurea hybrid resin. Component A consists of isocyanate deritavite and component B consists of polyol/amine derivative (Wiwa Wilhelm Wagner GmbH \& Co.KG 2015). The coating was done professionally by the manufacturer. The coating was professionally made by the manufacturer firm (depicted in Figure 2a). Two layers were applied to the floor using special polyurea coating machines (GAMA G-30 H) at a consumption of $1,7 \mathrm{~kg}-2,2 \mathrm{~kg}$ per $\mathrm{m}^{2}$ and the second layer application was started within maximum 6 hours after the first layer application.

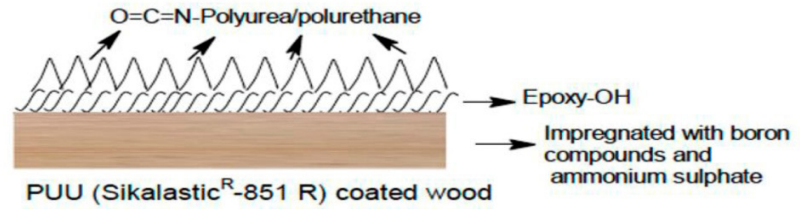

(a)

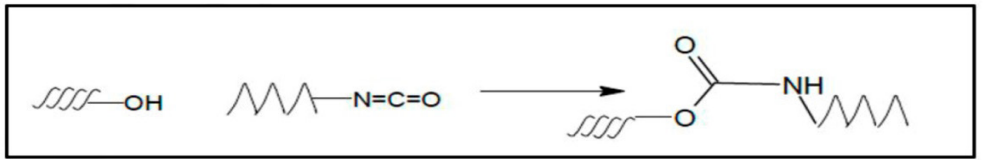

(b)

Figure 2: (a) PUU coated wood, (b) Reaction between epoxy and polyurea/polyurethane moieties.

A possible reaction, between polyurea/polyurethane and epoxy moieties which forms an epoxy-urea bond, and displayed the new interfacial chemical reaction between Sikafloor ${ }^{\mathbb{B}}-156$ and Sikalastic ${ }^{\mathbb{B}}-851 \mathrm{R}$, is illustrated in Figure $2 \mathrm{~b}$. The suggested/depicted crosslinking reaction in Figure $2 \mathrm{~b}$ that occurred between the hydroxyl groups of the epoxy resin and the isocyanate groups of the polyurea/polyurethane polymers are in accord with the previous studies (Attard et al. 2019, Chern et al. 1999, Chattopadhyay and Raju 2007).

\section{Colour test}

The color parameters $L^{*}, a^{*}$, and $b^{*}$ were determined by the CIEL*a* $\mathrm{b}^{*}$ method. The $L^{*}$ axis determines the lightness, whereas $a^{*}$ and $b^{*}$ are the chromaticity coordinates. The $+a^{*}$ and $-a^{*}$ parameters show the colors red and green, respectively. The $+b^{*}$ parameter represents yellow, whereas $-b^{*}$ represents blue. The $L^{*}$ value can vary from 100 (white) to zero (black) (Zhang 2003). The color difference, $\left(\Delta E^{*}\right)$ was measured according to ASTM D1536-58T (1964). The color changes were determined using Equation 2, Equation 3, Equation 4 and Equation 5.

$$
\begin{gathered}
\Delta a^{*}=a f^{*}-a i^{*} \\
\Delta b^{*}=b f^{*}-b i^{*} \\
\Delta L^{*}=L f^{*}-L i^{*} \\
\Delta E^{*}=\left[\frac{\left(\Delta a^{*}\right) 2+\left(\Delta b^{*}\right) 2+\left(\Delta L^{*}\right) 2}{2}\right]
\end{gathered}
$$

Where;

$\Delta a^{*}, \Delta b^{*}$, and $\Delta L^{*}$ represent the changes between the initial and final interval values. Five replicates were made for each treatment group. 


\section{Gloss test}

The gloss values of Oriental beech were measured according to ASTM D523-14 (2018) with a measuring device (Micro-TRI-Gloss). The chosen geometry was an incidence angle of $60^{\circ}$. Five replicates were made for each treatment group.

\section{Surface hardness test}

The surface hardness of Oriental beech was measured with the König hardness according to ASTM D 4366-14 (2014). The specimen was positioned on a panel table and a pendulum was placed on the panel surface. The pendulum was deflected for $6^{\circ}$ and released, triggering the start of the timer. The time needed to decrease the pendulum amplitude from $6^{\circ}$ to $3^{\circ}$ corresponded to the König hardness estimate. Five replicates were made for each treatment group.

\section{Accelerated weathering}

The accelerated weathering experiment was performed according to the American standard ASTM G154-06 (2016) in a Q-Panel Company (QUV) weathering tester with eight ultraviolet florescent lamps (UVA 340). The specimens were exposed to UV irradiation cycles for 8 hours, followed by condensation for 4 hours in a QUV apparatus for 250 hours. During the weathering period at the maximum intensity $(\lambda \max =340 \mathrm{~nm})$, the average irradiance was $0,89 \mathrm{~W} \mathrm{~m}^{-2}$. The temperature was $50{ }^{\circ} \mathrm{C}$ during the condensation period and it was $60{ }^{\circ} \mathrm{C}$ during the light irradiation period.

\section{Statistical evaluation}

Test results were analysed by a computerized SPSS statistical program include analysis of variance and Duncan test applied at $95 \%$ confidence level. Statistical evaluations were made on homogeneity groups (HG) where different letters reflected statistical significance.

\section{RESULTS AND DISCUSSIONS}

\section{Colour test}

The results regarding the color change values of the Oriental beech FRs impregnated and coated with PUU and EPR before and after accelerated weathering for 250 hours are given in Table 1 and Figure 3.

Table 1 shows $L^{*}, a^{*}$, and $b^{*}$ values of un-treated and non-coated (control) group, solely coated, and impregnated with FRs (boron chemicals and ammonium sulphate) and coated Oriental beech specimens and also shows the values of change $\Delta L^{*}, \Delta a^{*}$, and $\Delta b^{*}$, as well as $\Delta E^{*}$ of the Oriental beech after $250 \mathrm{~h}$ accelerated weathering. The retention values of Oriental beech wood impregnated with FRs were changed from $9,00 \mathrm{~kg} \cdot \mathrm{m}^{-}$ ${ }^{3}$ to $12,31 \mathrm{~kg} \cdot \mathrm{m}^{-3}$. Before accelerated weathering, all of the treatment groups were observed a decrease in $L^{*}$ values than that of un-treated and non-coated (control) group. While the $L^{*}$ value of the un-treated and noncoated (control) group was 68,19, it was changed from 49,75 to 58,29 for the impregnated and coated Oriental beech wood. $L^{*}$ value of the EPR coated Oriental beech was higher than that of PUU coated Orietal beech. The decrease in the $L^{*}$ value of Oriental beech showed that the wood became darker after the EPR and PU coated. These results are consistent with those of Baysal (2012), Üstün et al. (2016), and Şimşek and Baysal (2012). Our results showed that $a^{*}$ and $b^{*}$ values of un-treated and non-coated (control) group were 9,89 and 20,94. While $a^{*}$ and $b^{*}$ values were $-1,02$ and $-0,43$, respectively for PU coated Oriental beech, $a^{*}$ and $b^{*}$ values were 14,38 and 24,96, respectively for EPR coated Oriental beech. Moreover, while FRs impregnated and PU coated Oriental beech gave negative $L^{*}$ values, it gave positive $L^{*}$ values for FRs impregnated and EPR coated Oriental beech. Our results showed that $L^{*}$ values of EPR coated Oriental beech were highly higher than that of PUU coated Oriental beech. 
Table 1: Colour change values of Oriental beech before and after 250 hours of accelerated weathering.

\begin{tabular}{|c|c|c|c|c|c|c|c|c|c|c|c|c|}
\hline \multirow[t]{3}{*}{$\begin{array}{c}\text { FRs and coating } \\
\text { materials }\end{array}$} & & \multicolumn{6}{|c|}{ Colour values before accelerated weathering } & \multicolumn{3}{|c|}{$\begin{array}{c}\text { Colour values after } \\
250 \text { hours } \\
\text { accelerated } \\
\text { weathering } \\
\end{array}$} & \multicolumn{2}{|c|}{ Total colour changes } \\
\hline & & \multicolumn{2}{|c|}{$L^{*}$} & \multicolumn{2}{|c|}{$a^{*}$} & \multicolumn{2}{|c|}{$b^{*}$} & \multirow[b]{2}{*}{$\Delta L^{*}$} & \multirow[b]{2}{*}{$\Delta a^{*}$} & \multirow[b]{2}{*}{$\Delta b^{*}$} & \multirow[b]{2}{*}{$\Delta E^{*}$} & \multirow{2}{*}{$\begin{array}{l}\text { Homogeneity } \\
\text { group }\end{array}$} \\
\hline & $\begin{array}{r}\text { Retention } \\
\left(\mathrm{kg} / \mathrm{m}^{3}\right)\end{array}$ & Mean & SD & Mean & SD & Mean & SD & & & & & \\
\hline $\begin{array}{l}\text { Un-treated and non- } \\
\text { coated (control) } \\
\text { group }\end{array}$ & - & 68,19 & 2,34 & 9,89 & 0,69 & 20.94 & 1,16 & $-6,79$ & 2,71 & 5,22 & 8,98 & $\mathrm{BC}$ \\
\hline PUU & - & 53,66 & 0,11 & $-1,02$ & 0,01 & $-0,43$ & 0.08 & $-9,45$ & 4,91 & 14,89 & 18,30 & A \\
\hline $\mathrm{BA}+\mathrm{PUU}$ & 12,13 & 53,70 & 0,30 & $-1,04$ & 0,08 & -0.36 & 0,06 & $-7,73$ & 2,50 & 14,65 & 16,75 & A \\
\hline $\mathrm{BX}+\mathrm{PUU}$ & 9,00 & 53,40 & 0,45 & $-1,03$ & 0,01 & $-0,25$ & 0,08 & $-8,57$ & 3,29 & 15,60 & 18,10 & A \\
\hline AS+PUU & 12,30 & 53,32 & 0,25 & $-1,03$ & 0,01 & $-0,38$ & 0,04 & $-8,95$ & 4,37 & 15,61 & 18,51 & A \\
\hline$(\mathrm{BA}+\mathrm{BX})+\mathrm{PUU}$ & 9,34 & 53,76 & 0,12 & $-1,03$ & 0,08 & $-0,29$ & 0,09 & $-9,40$ & 4,58 & 15,14 & 18,46 & A \\
\hline EPR & - & 55,83 & 7,60 & 14,38 & 3,38 & 24,96 & 0,92 & $-7,38$ & 2,98 & 2,15 & 8,24 & $\mathrm{BC}$ \\
\hline BA+EPR & 11,27 & 49,75 & 7,55 & 14,80 & 0,69 & 23,37 & 3,74 & $-6,00$ & 0,50 & 0,40 & 6,03 & $\mathrm{CD}$ \\
\hline BX+EPR & 10,80 & 55,78 & 1,17 & 15,09 & 1,95 & 27,55 & 1,19 & $-3,39$ & 1,10 & 3,37 & 4,90 & $\mathrm{D}$ \\
\hline AS+EPR & 12,31 & 51,78 & 1,98 & 13,54 & 1,51 & 26,13 & 2,44 & $-4,88$ & 1,43 & 0,41 & 5,10 & $\mathrm{D}$ \\
\hline$(\mathrm{BA}+\mathrm{BX})+\mathrm{EPR}$ & 12,05 & 58,29 & 6,30 & 13,32 & 2,85 & 23,16 & 1,91 & $-7,30$ & 3,94 & 7,10 & 11,21 & $\mathrm{BC}$ \\
\hline
\end{tabular}

Note: PUU: Polyurea/Polyurethane hybrid resin, EPR: Epoxy resin, BA: Boric acid, BX: Borax, AS: Ammonium sulphate. SD: Standard deviation. Five replicates were made for each group. Homogeneity group was realized at $95 \%$ confidence level.

After $250 \mathrm{~h}$ of accelerated weathering, the negative $\left(\Delta L^{*}\right)$ values for un-treated and non-coated (control) group and other all FRs impregnated and coated Oriental beech were occurred. Therefore, the wood became rougher and darker after accelerated weathering. The darkening of Scots pine may be due to the degradation of lignin and other non-cellulosic polysaccharides (Hon and Chang 1985, Grelier et al. 2000, Petric et al. 2004).

The surface cellulose layer has the potential to stabilize the wood surface against discolouration. However, it can be affected by UV lights. Under the UV lights, a decrease in lignin content and at the same time an increase in crystalline cellulose content appears at the surface (Evans et al. 1996) . Lignin produces carbonyl groups when it exposes to singlet oxygen under the UV lights. The new carbonyl derivatives enable the absorbance of moisture that can decrease the resistance of wood against environmental effects (Varganici et al. 2021, Evans et al. 1996, Catto et al. 2016).

The main important consequence of wood photodegradation is surface color modification, accompanied by changes in the mechanical behavior (Varganici et al. 2021, Leary 1968). Photodegradation is formed by atmospheric oxygen via free radicals. The radicals formed during photodegradation are oxidized to yellow colored quinoid structures or to secondary chromophores which ensure further photodegradation (Leary 1968, Olsson et al. 2014, Varganici et al. 2021). Photodegradation produces a series of the most damaging effects on untreated wood, therefore coatings (EPR or EPR+PUU coatings) in this study have been used to protect wood surface against discoloration. Impregnated with FRs and coated with EPR or EPR+PUU coatings, as shown in Figure 3 and coatings protection on wood surface against discoloration are detailed in the literature (Varganici et al. 2021, Evans et al. 1996, Catto et al. 2016, Cogulet et al. 2018).

In order to covalently link the PUU coatings, epoxy resin (EPR) firstly applied to the wood surface. All wood components contain UV cleavable moieties: carboxyl, hydroxyl, carbonyl, double bonds. Coated with epoxy resin (EPR) process avoids occuring free radicals and produce the crosslinking between epoxy resin (EPR) and polyurea/polyurethane moieties. Interaction of EPR and PUU coatings stabilizes the wood surface against photoyellowing. Treated the surface impregnated with FRs and coated with EPR resin or impregnated with FRs and coated with EPR+PUU coatings led to a decrease in wood surface hydrophilicity and enhancement in fire resistance. (Rosu et al. 2016, Bodirlau et al. 2013) The effect was demonstrated by color differences decrease and an inhibition of surface darkening after exposure (Figure 3). This aspect is also reflected in the variation of chromatic coordinates $a^{*}$ and $b^{*}$ values (Table 1).

FRs impregnation caused increasing in the lightness than that of only coated Oriental beech in this study. It might be the FRs impregnation improved the stabilization of wood color in the visible region through a reduction in the lignin degradation that resulted from UV light, since the FRs impregnation process avoids occuring free radicals (Grelier et al. 2000). After $250 \mathrm{~h}$ of accelerated weathering, $\Delta a^{*}$ and $\Delta b^{*}$ values of 
un-treated and non-coated (control) group were found to be as 2,71 and 5,22 respectively. Un-treated and non-coated (control) group and all treatment froups showed positive $\Delta a^{*}$ and $\Delta b^{*}$ values after accelerated weathering. Positive $\Delta a^{*}$ and $\Delta b^{*}$ values determine that wood specimens surface maintained reddish and yellowish tone. While total color change $\left(\Delta E^{*}\right)$ was 8,98 for un-treated and non-coated (control) group, it was changed from 4,90 to 18,51 for all treatment groups after accelerated weathering. Colour change values showed that the best colour stability was observed with BX impregnated and EPR coated Oriental beech. In our study, except for BA+BX impregnation and EPR coating, other all impregnation and EPR coating caused decreasing $\Delta E^{*}$ of Oriental beech than that of un-treated and non-coated (control) group. The reduction in $\triangle E^{*}$ of FRs impregnated and EPR coated Oriental beech showed a positive effect to colour stability in previous studies (Yalinkiliç et al. 1999, Baysal 2008). In our study, only PUU coated and FRs impregnated and PUU coated Oriental beech showed higher $\left(\Delta E^{*}\right)$ values than that of un-treated and non-coated (control) group. Therefore, FRs impregnated and PUU coated Oriental beech showed the worst results in terms of $\left(\Delta E^{*}\right)$ values. There was a statitistically significant difference in $\Delta E^{*}$ values between PUU coated and un-treated and noncoated (control) group $(\mathrm{p} \leq 0,05)$.

\begin{tabular}{|c|c|c|}
\hline FRs and coating materials & Before accelerated weathering & $\begin{array}{c}\text { After 250 hours accelerated } \\
\text { weathering }\end{array}$ \\
\hline Control & & \\
\hline PUU & & \\
\hline EPR & & \\
\hline BA+PUU & & \\
\hline $\mathrm{BX}+\mathrm{PUU}$ & & \\
\hline $\mathrm{AS}+\mathrm{PUU}$ & & \\
\hline$(\mathrm{BA}+\mathrm{BX})+\mathrm{PUU}$ & & \\
\hline $\mathrm{BA}+\mathrm{EPR}$ & & \\
\hline $\mathrm{BX}+\mathrm{EPR}$ & & \\
\hline $\mathrm{AS}+\mathrm{EPR}$ & & \\
\hline$(\mathrm{BA}+\mathrm{BX})+\mathrm{EPR}$ & & \\
\hline
\end{tabular}

Figure 3: Colour changes of Oriental beech impregnated with FRs and coated with PUU and EPR after 250 $\mathrm{h}$ accelerated weathering.

\section{Gloss}

Gloss values of Oriental beech measured before and after accelerated weathering, and statistical test results are given in Table 2. Except for BA+BX impregnation before EPR coating, other FRs treatments before EPR coating caused to decrease gloss values of Oriental beech in some extent. It may be due to impregnation with solutions might limit the glossiness up to a point in Oriental beech before weathering, probably owing to absorption and dispersion of reflected rays by salt crystals prominent in the large lumens of the vessels in the wide earlywood sections of the grains. Photoactive ions on the wood surface were assumed to cause some loss in gloss of FRs impregnated and EPR coated Oriental beech wood surfaces before weathering (Yalınkılıç et al. 1999). This result is consistent with the glossiness values of CCB impregnated Scots pine before varnish 
coating (Yalınkılıç et al. 1999). However, gloss values were highly increased for FRs impregnated and PUU coated of Oriental beech than that of only PUU coated Oriental beech before accelerated weathering.

Accelerated weathering decreased gloss values of un-treated and non-coated (control) group and FRs impregnated and PU and EPR coated Oriental beech. Çakıcıer et al. (2011) reported that decreases in glossiness of wood species coated with one and two component water-based varnishes after accelerated weathering for $216 \mathrm{~h}$ and $432 \mathrm{~h}$. Türkoğlu et al. (2015) investigated gloss changes of copper based chemicals impregnated and then polyurethane and synthetic varnishes coated Scots pine (Pinus sylvestris) and Oriental beech (Fagus orientalis) after 3 months of weathering. Our results showed that except for BA impregnated and PUU coated Oriental beech, other all FRs impregnation before PUU and EPR coating showed protective effect in terms of preventing loss of gloss after accelerated weathering. However, while there was a statistically significant difference in gloss losses values between EPR coated Oriental beech and FRs impregnated and EPR coated Oriental beech, there was no statistically significant difference between in gloss losses values between PUU coated Oriental beech and FRs impregnated and PUU coated Oriental beech.

Table 2: Gloss change values of test specimens before and after 250 hours of accelerated- weathering.

\begin{tabular}{|c|c|c|c|c|c|c|c|}
\hline \multirow[t]{3}{*}{$\begin{array}{c}\text { FRs and coating } \\
\text { materials }\end{array}$} & & \multirow{2}{*}{\multicolumn{2}{|c|}{$\begin{array}{l}\text { Gloss values before } \\
\text { acceleratedweathering }\end{array}$}} & \multirow{2}{*}{\multicolumn{2}{|c|}{$\begin{array}{c}\text { Gloss values after } 250 \\
\text { hours accelerated } \\
\text { weathering }\end{array}$}} & \multicolumn{2}{|c|}{$\begin{array}{c}\text { Gloss losses values after } 250 \\
\text { hours accelerated weathering } \\
(\%)\end{array}$} \\
\hline & \multirow[b]{2}{*}{$\begin{array}{c}\text { Retention } \\
\left(\mathrm{kg} / \mathrm{m}^{3}\right)\end{array}$} & & & & & $60^{\circ}$ & Homogeneity \\
\hline & & Mean & SD & Mean & SD & & oroun \\
\hline $\begin{array}{l}\text { Un-treated and } \\
\text { non-coated } \\
\text { (control) group }\end{array}$ & - & 2,88 & 0,08 & 2,49 & 0,15 & $-13,54$ & $\mathrm{CDE}$ \\
\hline PUU & - & 28,06 & 10,16 & 25,00 & 9,51 & $-10,90$ & $\mathrm{BC}$ \\
\hline $\mathrm{BA}+\mathrm{PUU}$ & 12,13 & 39.72 & 12,69 & 33,65 & 7,91 & $-15,28$ & $\mathrm{CDE}$ \\
\hline $\mathrm{BX}+\mathrm{PUU}$ & 9,00 & 69,62 & 12,19 & 64,86 & 10,17 & $-6,83$ & $\mathrm{~B}$ \\
\hline AS+PUU & 12,30 & 69,66 & 4,91 & 65,07 & 9,98 & $-6,58$ & B \\
\hline$(\mathrm{BA}+\mathrm{BX})+\mathrm{PUU}$ & 9,34 & 77,96 & 4,53 & 69,60 & 8,83 & $-10,72$ & $\mathrm{BC}$ \\
\hline EPR & - & 39,68 & 11,67 & 30,95 & 14,76 & $-22,00$ & $\mathrm{E}$ \\
\hline $\mathrm{BA}+\mathrm{EPR}$ & 11,27 & 13,30 & 4,32 & 11,65 & 3,75 & $-12,40$ & $\mathrm{C}$ \\
\hline $\mathrm{BX}+\mathrm{EPR}$ & 10,80 & 29,56 & 7,64 & 25,15 & 7,47 & $-14,91$ & $\mathrm{CD}$ \\
\hline $\mathrm{AS}+\mathrm{EPR}$ & 12,31 & 29,30 & 8,67 & 27,60 & 6,41 & $-5,80$ & $\mathrm{~A}$ \\
\hline$(\mathrm{BA}+\mathrm{BX})+\mathrm{EPR}$ & 12,05 & 59,68 & 15,96 & 55,65 & 10,19 & $-6,75$ & B \\
\hline
\end{tabular}

Note: PUU: Polyurea/Polyurethane hybrid resin, EPR: Epoxy resin, BA: Boric acid, BX: Borax, AS: Ammonium sulphate. SD: Standard deviation. Five replicates were made for each group. Homogeneity group was realized at $95 \%$ confidence level.

\section{Surface hardness}

The surface hardness values of Oriental beech before and after $250 \mathrm{~h}$ accelerated weathering and the percentage change in surface hardness are given in Table 3. The pendulum hardness test was used to measure the surface hardness values. The simple principle for pendulum hardness test is that the harder surface displays the greater the oscillation time of the pendulum.

While the surface hardness value of un-treated and non-coated (control) group was 34,60, it was 37,40 and 67,20 for PUU and EPR coated Oriental beech wood specimens before accelerated weathering. There was not a statistically significant difference in surface hardness changes between PUU coated Oriental beech and un-treated and non-coated (control) group after accelerated weathering. FRs impregnation before PU and EPR coating caused to slightly decrease surface hardness of Oriental beech before accelerated weathering, however, after accelerated weathering $250 \mathrm{~h}$, there were an increasing affect for EPR coatings and decreasing affect for PUU coatings, except impregnated with borax (BA) for PUU coatings. Baysal (2012) investigated the effect of the surface hardness changes of Scots pine specimens treated with wolmanit-CB, tanalith-E, and adolit-KD5 and coated with synthetic varnish. They found that impregnation with chemicals before synthetic varnish coating caused to decrease surface hardness values of Scots pine. Our results showed that while FRs impregnation before coating caused to decrease surface hardness values of Oriental beech before accelerated weathering, FRs impregnation increases the surcafe hardness for both EPR and PUU coatings, except BXPUU and AS-PUU, after accelerated weathering. The effect of FRs treatment on surface hardness was probably due to their different compositions. Active constituents in the formulations might have some influence on the curing process of PUU and EPR. Surface hardness values of FRs impregnated and EPR coated wood were higher than that of FRs impregnated and PUU coated wood after accelerated weathering. The surface 
hardness values of PU and EPR coated and un-treated and non-coated (control) group were decreased after $250 \mathrm{~h}$ accelerated weathering. Yalınkılıç et al. (1999), Baysal (2008), and Türkoğlu et al. (2015) studied the surface hardness values of some weathered wood species. They found that weathering caused to decrease the surface hardness values of the wood. The combined effect of moisture, UV light, and temperature could degrade lignocellulosic structure of the wood. Therefore, the degradation products became water-soluble and were leached out resulting in erosion of the wood surface (Meijer 2001). BA impregnation before PUU coating resulted in 2,58\% increase of the surface hardness of Oriental beech after $250 \mathrm{~h}$ accelerated weathering.

Moreover, other FRs treatment on PUU caused to decrease surface hardness loss. For example, surface hardness decrease was $16,22 \%$ for only PUU coated Oriental beech, it was changed 2,77 \% to 15,84 \% for other FRs treatment on PUU.

Table 3: Surface hardness values of test specimens before and after 250 hours of accelerated weathering.

\begin{tabular}{|c|c|c|c|c|c|c|c|}
\hline \multirow{2}{*}{$\begin{array}{c}\text { FRs and coating } \\
\text { materials }\end{array}$} & \multirow{2}{*}{$\begin{array}{c}- \\
\text { Retention } \\
\left(\mathrm{kg} / \mathrm{m}^{3}\right)\end{array}$} & \multicolumn{2}{|c|}{$\begin{array}{c}\text { Surface hardness values } \\
\text { before acceleratedweathering }\end{array}$} & \multicolumn{2}{|c|}{$\begin{array}{c}\text { Surface hardness after } 250 \\
\text { hours accelerated weathering } \\
(\%)\end{array}$} & \multicolumn{2}{|c|}{$\begin{array}{c}\text { Surface hardness changes (\%) } \\
\text { after } 250 \text { hours accelerated } \\
\text { weathering }\end{array}$} \\
\hline & & Mean & SD & Mean & SD & Mean & $\begin{array}{l}\text { Homogeneity } \\
\text { group }\end{array}$ \\
\hline $\begin{array}{l}\text { Un-treated and } \\
\text { non-coated } \\
\text { (control) group }\end{array}$ & - & 34,60 & 4,21 & 41,80 & 1,48 & $-14,62$ & $\mathrm{E}$ \\
\hline PUU & - & 37,40 & 5,54 & 31,33 & 9,60 & $-16,22$ & $\mathrm{E}$ \\
\hline $\mathrm{BA}+\mathrm{PUU}$ & 12,13 & 36,80 & 3,56 & 37,75 & 3,77 & 2,58 & CD \\
\hline $\mathrm{BX}+\mathrm{PUU}$ & 9,00 & 35,00 & 1.87 & 29,87 & 10,11 & $-14,65$ & $\mathrm{E}$ \\
\hline AS+PUU & 12,30 & 35,47 & 3,13 & 29,85 & 5,77 & $-15,84$ & $\mathrm{E}$ \\
\hline$(\mathrm{BA}+\mathrm{BX})+\mathrm{PUU}$ & 9,34 & 34,20 & 1,78 & 33,25 & 2,98 & $-2,77$ & $\mathrm{D}$ \\
\hline EPR & - & 67,20 & 7,69 & 30,75 & 2,06 & $-54,24$ & $\mathrm{G}$ \\
\hline $\mathrm{BA}+\mathrm{EPR}$ & 11,27 & 51,35 & 5,27 & 60,25 & 7,80 & 17,33 & $\mathrm{~A}$ \\
\hline $\mathrm{BX}+\mathrm{EPR}$ & 10,80 & 61,40 & 14,48 & 82,75 & 11,78 & 34,77 & A \\
\hline $\mathrm{AS}+\mathrm{EPR}$ & 12,31 & 53,49 & 7,70 & 57,00 & 1,82 & 6,56 & $\mathrm{C}$ \\
\hline$(\mathrm{BA}+\mathrm{BX})+\mathrm{EPR}$ & 12,05 & 61,60 & 5,81 & 70,89 & 10,81 & 15,08 & $\mathrm{~B}$ \\
\hline
\end{tabular}

Note: PUU: Polyurea/Polyurethane hybrid resin, EPR: Epoxy resin, BA: Boric acid, BX: Borax, AS: Ammonium sulphate. SD: Standard deviation. Five replicates were made for each group. Homogeneity group was realized at $95 \%$ confidence level.

Hovewer, FRs treatments on EPR coated caused to increase surface hardneess values of Oriental beech after $250 \mathrm{~h}$ accelerated weathering. While the surface hardness decreases of only EPR coated Oriental beech was $54,24 \%$ after accelerated weathering, it increased from $6,56 \%$ to $34,77 \%$ for FRs impregnated and EPR coated Oriental beech after accelerated weathering. There was a statistically significant differences in surface hardness changes between EPR coated and FRs impregnated and only EPR coated Oriental beech wood after accelerated weathering. Türkoğlu et al. (2015) investigated the surface hardness changes of Oriental beech and Scots pine impregnated with chromated copper arsenate and some copper-based chemicals such as adolit KD-5 and tanalith-e and then coated with polyurethane and synthetic varnishes after weathering. They found that the surface hardness values of impregnated and varnish coated wood surface were higher than that solely varnish coated wood surface after weathering. This was because the impregnation materials increased hardness and wood samples had a harder varnish layer (Keskin et al. 2011). Our results are compatible with these researcher's findings. In our study, while FRs impregnation before PUU coating decreased surface hardness loss, it increased the surface hardness values of Oriental beech after accelerated weathering. It can be concluded from our results that FRs impregnated epoxy coatings (EPR+FRs) have better hardness values compared to FRs impregnated polyurethane/polyurea coatings (PUU+FRs). This could be the reason of crosslinking density of the epoxy coatings is higher than polyurethane/polyurea coatings.

\section{CONCLUSIONS}

In this study, colour, gloss, and surface hardness changes of Oriental beech wood impregnated with FRs and EPR and PUU coated Oriental beech wood were investigated after accelerated weathering.

FRs impregnation and EPR and PUU coatings caused decreasing $L^{*}$ values of Oriental beech. While un-treated and non-coated (control) group and all treatment groups showed negative $\Delta L^{*}$ values, they gave positive $\Delta a^{*}$ and $\Delta b^{*}$ values after accelerated weathering. Colour stability of EPR coatings of Oriental beech were higher than that of PUU coated Oriental beech. The best colour stability was obtained with BX impregnated and EPR coated Oriental beech. Coating with PUU and EPR increased gloss values of Oriental beech before accelerated weathering. Weathering caused decreasing gloss values of control and PUU and EPR 
coated Oriental beech. However, except for BA impregnation and PUU coating, FRs impregnation before PUU and EPR coating caused decreasing gloss losses after accelerated weathering. While FRs treatment before PUU coating decreased the surface hardness losses, it increased the surface hardness of EPR coated Oriental beech after acelerated weathering.

In conclusion, FRs treatments before PUU and EPR coatings generally resulted in higher colour stability, lower gloss losses, and higher surface hardness values after accelerated weathering. Thus, Oriental beech wood surfaces can be impregnated with FRs (boron chemicals and AS) before PUU and EPR coatings for improving surface characteristics of wood surface in weathering conditions.

\section{ACKNOWLEDGEMENTS}

This manuscript was prepared from some results of the Phd thesis of Çağlar ALTAY, who is studying for a doctorate in Woodworking Industrial Engineering at Muğla Sitkı Koçman University Institute of Science. This study is supported by the Scientific Research Project BAP-20/099/01/2 by Muğla Sitkı Koçman University.

\section{REFERENCES}

Anderson, E.L.; Pawlak, Z.; Owen, N.L.; Feist, W.C. 1991. Infrared studies of wood weathering. Part I: Softwoods. Appl Spectrosc 45(4): 641- 647. https://www.osapublishing.org/as/abstract.cfm?URI=as-45-4-641.

Aslan, S.; Özkaya, K. 2009. Investigation of combustion resistance of wood-based panels treated with different chemicals. Turk J For 2: 122-140. https://www.cabdirect.org/cabdirect/abstract/20063087353

ASTM.1964. Tentative method of test color difference using the color master differential colorimeter. ASTM D1536-58.1964. Replaced by D2244 ASTM: West Conshohocken, PA, USA. https://www.astm.org/ DATABASE.CART/WITHDRAWN/D1536.htm

ASTM. 2018. Standard test method for specular gloss. ASTM D523-14. 2018. ASTM: West Conshohocken, PA, USA. https://www.astm.org/Standards/D523

ASTM. 2014. Standard test methods for hardness of organic coatings by pendulum damping tests. ASTM D4366-14. 2014. ASTM:West Conshohocken, PA, USA. https://www.astm.org/DATABASE.CART/ HISTORICAL/D4366-14.htm

ASTM. 2016. Standard practice for operating fluorescent light apparatus for UV exposure of nonmetallic materials. ASTM G154-06. 2016. ASTM: West Conshohocken, PA, USA. https://www.astm.org/DATABASE. CART/HISTORICAL/G154-06.htm.

ASTM. 2017. Standard test method for wood preservatives by laboratory soil-block cultures (Withdrawn 2016). ASTMD 1413-07e1. 2017. ASTM: West Conshohocken, PA, USA. https://www.astm.org/DATABASE. CART/HISTORICAL/D1413-07.htm.

Abed, M.S.; Ahmed, P.S.; Oleiwi, J.K.; Fadhil, B.M. 2020. Low velocity impact of Kevlar and ultra high molecular weight polyethylene (UHMWPE) reinforced epoxy composites. Model Mater Struct 16(6): 1617-1630. https://doi.org/10.1108/MMMS-09-2019-0164

Attard, T.L; He, L.; Zhou, H. 2019. Improving damping property of carbon-fiber reinforced epoxy composite, through novel hybrid epoxy-polyurea interfacial reaction. Comp Part B 164: 720-731. https://doi.org/10.1016/j.compositesb.2019.01.064.

Babahan, I.; Zheng, Y.; Soucek, M.D. 2020. New bio based glycidal epoxides. Prog Org Coat 142: 105580. https://doi.org/10.1016/j.porgcoat.2020.105580.

Baysal, E. 2012. Surface characteristics of CCA treated Scots pine after accelerated weathering. Wood Res 57(3): 375-382. http://www.woodresearch.sk/intro.php. 
Baysal, E. 2008. Some physical properties of varnish coated wood preimpregnated with copperchromated boron (CCB) after 3 months of weathering exposure in Southern Eagen Sea region. Wood Res 53(1): 43-54. http://www.woodresearch.sk/intro.php.

Budakçı, M. 2006. Effect of outdoor exposure and bleaching on surface color and chemical structure of Scots pine. Prog Org Coat 56(1): 46-52. https://doi.org/10.1016/j.porgcoat.2006.01.018

Bodirlau, R.; Teaca, C.A.; Rosu, D.; Rosu, L.; Varganici, C.D.; Coroaba, A. 2013. Physico-chemical properties investigation of softwood surface after treatment with organic anhydride. Cent Eur $J$ Chem 11: 2098-2106. https://doi.org/10.2478/s11532-013-0337-X.

Catto, A.L.; Montagna, L.S.; Almeida, S.H.; Silveira, RM.; Santana, R.M. 2016. Wood plastic composites weathering: effects of compatibilization on biodegradation in soil and fungal decay. Int Biodeter Biodegr 109: 11-22. https://doi.org/10.1016/j.ibiod.2015.12.026.

Chern, Y.C.; Tseng, S.M.; Hsieh, K.H. 1999. Damping properties of interpenetrating polymer networks of polyurethane-modified epoxy and polyurethanes. J Appl Polym Sci 74(2): 328-335. https://doi.org/10.1002/ (SICI)1097-4628(19991010)74:2<328::AID-APP14>3.0.CO;2-W.

Chattopadhyay, D.K.; Raju, K.V.S.N. 2007. Structural engineering of polyurethane coatings for high performance applications. Prog Polym Sci 32(3):352-418. https://doi.org/10.1016/j.progpolymsci.2006.05.003

Cogulet, A.; Blanchet, P.; Landry, V. 2018. The multifactorial aspect of wood weathering: a review based on a holistic approach of wood degradation protected by clear coating. BioResources 13: 2116-2138. https://bioresources.cnr.ncsu.edu/wp-content/uploads/2017/12/BioRes_13_1_2116_Review_-Cogulet_BL_ Multifactorial_Aspect_Wood-Weathering_Coating_Degradat_12518.pdf

Çakıcıer, N.; Korkut, S.; Korkut, D.S.; Kurtoğlu, A.; Sönmez, A. 2011. Effects of QUV accelerated aging on surface hardness, surface roughness, glossiness, and color difference for some wood species. Int $J$ Phys Sci 6(8): 1929-1939. https://academicjournals.org/article/article1380727968_Cakicier\%20et\%20al.pdf

Evans, P.D.; Michell, A.J.; Schmalzl, K.J. 1992. Studies of the degradation and protection of wood surfaces. Wood Sci Technol 26: 151-163. https://link.springer.com/article/10.1007/BF00194471.

Evans, P.D.; Thay, P.D.; Schmalz, K.J. 1996. Degradation of wood surfaces during natural weathering. Effects on lignin and cellulose and on the adhesion of acrylic latex primers. Wood Sci Technol 30: 411-422. https://doi.org/10.1007/BF00244437 .

González-Laredo, F.R.; Rosales-Castro, M.; Rocha-Guzmán, N.E.; Gallegos-Infante, J.A.; MorenoJiménez, M.R.; Karchesy, J.J. 2015. Wood preservation using natural products. Madera Bosques 21: 63-76. https://myb.ojs.inecol.mx/index.php/myb.

Gündüz, A.; Baysal, E.; Türkoğlu, T.; Küçüktüvek, M.; Altay, Ç.; Peker, H.; Toker, H. 2019. Accelerated weathering performance of Scots Pine preimpregnated with copper based chemicals before varnish coating. Part II: coated with water based varnish. Wood Res 64(6): 987-998. http://www.woodresearch. sk/intro.php.

Gündüz, A.; Baysal, E.; Türkoğlu, T.; Altay, Ç.; Küçüktüvek, M.; Toker, H.; Peker, H. 2020. Accelerated weathering performance of scots pine preimpregnated with copper-based chemials before varnish coating. Part I: coated with cellulosic and polyurethane varnish. Color Tech 136(1): 34-44. https://doi.org/10.1111/cote.12435.

Grelier, S.; Castellan, A.; Kamdem, D.P. 2000. Photo-protection of copper amine treated pine. Wood Fiber Sci 32(2): 196-202. https://wfs.swst.org/index.php/wfs/article/view/240.

Hon, D.N.S.; Chang, S.T. 1985. Photoprotection of wood surfaces by wood-ion complexes. Wood Fiber Sci 17(1) : 92-100. https://wfs.swst.org/index.php/wfs/article/view/325.

Keskin, H.; Atar, M.; Korkut, S.; Korkut, D.S. 2011. Impact of impregnation with Imersol Aqua on the surface adhesion strength of synthetic, acrylic, polyurethane, and water-based varnishes. Pigment Resin Technol 40: 154-160. https://doi.org/10.1108/03699421111130414. 
Leary, G.J. 1968. Photochemical production of quinoid structures in wood. Nature 217: 672-673. https://doi.org/10.1038/217672b0.

Meijer, M. 2001. Review on the durability of exterior wood coatings with reduced VOC-content. Prog Org Coat 43(4): 217-225. https://doi.org/10.1016/S0300-9440(01)00170-9.

Olsson, S.K.; Johansson, M.; Westin, M.; Östmark, E. 2014. Reactive UVabsorber and epoxy functionalized soybean oil for enhanced UV protection of clear coated wood. Polym Degrad Stab 110: 405414. https://doi.org/10.1016/j.polymdegradstab.2014.09.017.

Özgenç, O.; Yıldız, Ü.C.; Yıldız, S. 2013. The wood surface protection with some new generation wood preservatives and coating processings against weathering conditions. $A C U J 14: 203-215$. http://ofd.artvin. edu.tr/tr/pub/issue/25321/267466

Peker, H. 1997. Mobilya üst yüzeylerinde kullanılan verniklere emprenye maddelerinin etkileri. Phd. Thesis, Karadeniz Technical University, Forest Industry Engineering Department, Trabzon, Turkey.(In Turkish). https://tez.yok.gov.tr/UlusalTezMerkezi/tezSorguSonucYeni.jsp.

Petric, M.; Kricej, B.; Humar, M.; Pavlic, M.; Tomazic, M. 2004. Patination of cherry wood and spruce wood with ethanolamine and surface finishes. Surf Coat Int 87: 195-201. https://link.springer.com/ article/10.1007/BF02699635.

Rosu, D.; Mustata, F.; Tudorachi, N.; Varganici, C.D.; Rosu, L.; Musteata, V.E. 2016. A study on coating properties of an epoxy system hardened with maleinized castor oil. Prog Org Coat 99: 480-489. https://www.sciencedirect.com/science/article/pii/S0300944016303484

Sivrikaya, H.; Hafizoglu, H.; Yasav, A.; Aydemir, D. 2011. Natural weathering of oak (Quercus petraea) and chestnut (Castanea sativa) coated with various finishes. Color Res Appl 36(1): 72-78. https://doi.org/10.1002/col.20581.

Söğütlü, C.; Döngel, N. 2009. The effect of the impregnate process of wooden material to color changes and surface roughness. Politeknik Dergisi 12(3): 179-184.

Şimşek, H.; Baysal, E. 2012. An investigation on colour and gloss changes of wood impregnated with borates. Wood Res 57(2): 271-277. http://www.woodresearch.sk/intro.php.

Türkoğlu, T.; Baysal, E.; Toker, H. 2015. The effects of natural weathering on color stability of impregnated and varnished wood materials. Adv Mater Sci Eng 2015: 526570. http://dx.doi.org/10.1155/2015/526570.

Üstün, S.; Baysal, E.; Türkoğlu, T.; Toker, H.; Saçlı, C.; Peker, H. 2016. Surface characteristics of Scots pine treated with chemicals containing some copper compounds after weathering. Wood Res 61(6): 903914. http://www.woodresearch.sk/intro.php.

Varganici, C.D.; Rosu, L.; Rosu, D.; Mustata, F.; Rusu, T. 2021. Sustainable wood coatings made of epoxidized vegetable oils for ultraviolet protection. Environ Chem Lett 19: 307-328. https://doi.org/10.1007/ s10311-020-01067-w.

Wiwa Wilhelm Wagner GmbH \& Co.KG 2015. Two-component hybrid coating for roofs. IST Inter Surfa Tech 8:10-11. https://www.ist-surfacetechnology.com/magazine/archive/article/article-2045598.html

Yalınkılıç, M.K.; İlhan, R.; Imamura, Y.; Takahashi, M.; Demirci, Z.; Yalınkılıç, A.C. 1999. Weathering durability of CCB-impregnated wood for clear varnish coatings. $J$ Wood Sci 45: 502-514. https://link.springer.com/article/10.1007/BF00538961.

Zhang, X. 2003. Photo-resistance of alkyl ammonium compound treated wood. M.S.c. Thesis, The University of British Columbia, Vancouver, Canada. https://open.library.ubc.ca/cIRcle/collections/ ubctheses/831/items/1.0075034. 